\section{New I.C.I. Laboratories for Fundamental Research}

IMPERIAL C EMrCaL IndustriEs, LTD., have leased the house and laboratories at The Frythe, Welwyn, Herts, for fong-term general and academic research in branghes of biological," chemical and physical science Among the subjects to be studied are the antiblotic products of moulds, kinetics of continuous chofnical reactions and the deformation of materials udder high stresses of short duration. Work will also be done on the design of industrial instruments and on industrial toxicology. The new laboratories will eventually house twenty or more senior research workers, with assistants and administrative staff. Some of the staff have already been recruited, but have hitherto been scattered in various localities while engaged on war-work. The premises at The Frythe are intended as temporary accommodation until a site at Butterwick Wood, near St. Albans, which was originally selected, can be developed. The activities of the Butterwick Research Laboratories will be completely independent of all other I.C.I. research departments, which will continue to be concerned with more specifically industrial problems.

\section{Colour Receptors in the Human Fovea}

Dr. F. W. EDridGe-Green suggests that, if Prof. Hartrids's observations in Nature of July 20 were correct, the stars should appear to change colour as their light falls upon different cones of the fovea. Jrof. Hartridge, in reply, says "Dr. EdridgeGreen /s quite right. On either the three-colour theo y of Thomas Young, or on its modern counterpay, the Wundt-Granit hypothesis, one would expect a point source, and therefore a star, to undergo subjective changes of colour as its image is caused to move over the retina. Some stars do change colour, a fact usually explained on purely physical grounds; I have also noticed changes of colour of local sources under conditions where physical explanations did not appear to apply (Nature, July 20, p. 97). Why, it may be asked, are such colour variations so seldom seen when the eye is being used in normal vision ? The answer is not a simple one, since many factors play a part. In the first place the retinal image, even of a point source, falls on a considerable area of retina. This is partly due to diffraction, and partly due to aberrations. In consequence, many photoreceptors are usũally stimulated at the same time. But further, colours which would normally be seen are eliminated by the anti-chromatic responses. In the third place, there is a process which tends to smooth out differences in response. This is now under further investigation, because it is hindering progress. When a method has been found of putting this process temporarily out of action, a new avenue of approach to the essential problem of vision will probably have been found."

\section{Catalogue of Huxley's Papers and Correspondence}

IN 1937, through the good offices of the Friends of the National ibraries, the correspondence and papers of Thomgs Henry Huxley were presented to the Imperig/ College of Seience and Technology, London. During the War, these papers were necessarily inaccessolole, but as soon as it became safe to bring them at of hiding, the governing body of the College decided that they should at once be made available, and the work of arranging and cataloguing them was entrusted to Mr. Warren R. Dawson, who has had much experience of work of this nature and has previously published catalogues of various collections of scientific papers such as the Smith manuscripts of the Linnean Society, and the entire manuscript collection of the Medical Society of London. The arrangement of the Huxley Papers has been accomplished, and a complete descriptive catalogue of the entire collection has been prepared; it will be published shortly by Messrs. Macmillan \& Co., Ltd., St. Martin's Street, London, W.C.2. The collection comprises some five thousand letters, and a large mass of other papers covering the entire range of Huxley's manifold activities--biology, anthropology, education, philosophy, and many other subjects in which he interested himself, and upon which he left his mark. The catalogue should be of great value in the study of the history of science during a brilliant phase of its development.

\section{Publication and Distribution of Scientific Papers \\ In a paper prespnt $\mathrm{h}$ before the American Associa.} tion for the Advadement of Science at its Cleveland meeting a v6of tember 11, 1944, Zeliaette Troy, librerian of the Boyce Thompson Institute for Plant R.sperch reiterated earlier proposals for dealing with the Wehanical side of the publication and distribution of cientific papers originally outlined in Special Libraries in July-August 1943. It is urged that the whole problem is purely a matter of good business management and should be considered factually. To centralize the printing of scientific papers and abstracts in one establishment covering all sciences and technologies-presumably, one for each countrywould offer all the advantages of modern massproduction methods in the mechanical aspects such as paper and ink supplies, printing and indexing by specialists, apart from the comprehensive service which could be offered to any subseriber or reader in the field he designated. The central organisation is visualized as a limited company in which the shares are held by the various organisations interested in publishing and purchasing scientific and technical papers; original research articles and summaryreview articles would be published and sold in much the same way as U.S. patent specifications, and the abstracts journal would be analogous to the Official Patent Office Gazette.

\section{Industrial Development of Northern Rhodesia}

THE first dop $w$ of the Advisory Committee on Industrial Dekffopment, Northern Rhodesia (Lusaka : Ggverfoperinter, 1946. 1s.) recommends the renexal of a nomber of customs agreements as well as of 2al statement of policy on the extent to which tef African will be allowed to participate in semiskilled or skilled labour, and the enactment of legislation to prevent dumping. The Comnittee recom. mends that the Government's undertaking to develop Ndola as the commercial and distributive centre of the Copperbelt be rescinded, and secondary industries be allowed to select any location convenient for them, including the four Copperbelt townships. It also welcomes the formation of a Statistical Department as visualized by the Central African Council, and in the meantime requires the services of a full-time technical officer. Of a number of agricultural products examined with a view to their processing or industrial utilization, cassava holds possibilities for the production of starch as a secondary industry. Evidence is against the successful establishment of a cotton- 
growing industry, but there are a number of essential oils the development of which might repay close investigation, and further experiment on the cultivation of tung oil by the Agricultural Department is recommended. After a thorough examination of all phases of a cement factory in Northern Rhodesia, the Committee considers that the establishment of this industry holds little prospect of financial success unless a territorial consumption of 20,000 tons a year can be guaranteed for at least fifteen years. Complete information on the coal resources of the Territory is being assembled, and the manufacture of cycles and fibre board, and the formation of a central logging organisation have also received attention. Proposals are advanced for developing the tourist industry, and a memorandum has been submitted to the Government on the importance of increasing the existing power services. There are good technical and economic prospects for a small sheet metal industry to process utensils for African trade, and support is urged for the establishment of the fishing industry on a sound basis. Publication in booklet form of complete information on the mineral resources of Northern Rhodesia is recommended.

\section{Safety of Malaysian Hepaticæ in Germany}

THE Farlow Herbarium of Harvard University has received woy that a valuable collection of more than three thousand specimens of Malaysian Hepaticæ, chiefly opiphytic Lejeuneaceæ gathered by Dr. Frans yerdoorn as well as some other collections assembled by him between 1925 and 1936, which were on loan, at the outbreak of the War, to the Botanical Ingtitute of the University of Jena, is safe. Prof. Th. Herzog who, with a number of assistants and graduate students, is working on this collection writes that he placed most of it, during the early war years, for safeguarding in a country home near Jena. This house was almost entirely destroyed by a bomb; the specimens, however, were found in undamaged condition in the wreckage of the basement. They were later removed to a part of the basement at the Botanical Institute. This building and most of the basement were entirely destroyed at a later date when nine students were killed and the director, Prof. Renner, was seriously wounded. The bryological collections were fortunately in a wing where the basement withstood the bombing, and work on them is now being continued by Prof. Herzog and his assistants, Drs. Benedict and Schuchardt.

\section{Sixth International Congress on Experimental Cell Research}

THe Sixth International Congress on Experimental Cell Resear h is to be held in Stockholm in July 1947. The Congress will be organised by a Swedish working oommittee. Prof. J. Runnström of WennerGrens Institute will act as chairman for the Conference and Pyof. T. Caspersson and Dr. H. Hyden of the Karo/nska. Institute as secretaries. A preliminary programme will be published at the beginning of the autumn. The Conference will include a series of symposia on important problems in experimental cell research from the physico-chemical, physiological and morphological aspects. The Swedish organising committee hopes that cell research workers of all kinds will take advantage of this occasion for exchanging experiences and renewing contact with their colleagues. Suggestions or questions regarding the Conference should be sent to the secretaries.

\section{The Night Sky in September}

Furs moon occurts in Sept. 11d. 09h. 59m. U.T. and new thon on 5 st. 25d. $08 \mathrm{~h}$. $45 \mathrm{~m}$. The following conjunct ons wit the moon take place: Sept. 21d. o4h Saturio S. ; Sept. 27d. 13h., Jupiter $3^{\circ}$ S. ; \$e) 27 d. 1 h., Mars $4^{\circ}$ S. ; Sept. 29d. 00h., Venus t). In addition to these conjunctions with the moon, the following conjunctions occur: Sept. 4d. 03h., Venus in conjunction with Jupiter, Venus $3.5^{\circ}$ S. ; Sept. 25d. 04h., Mars in conjunction with Jupiter, Mars $1 \cdot 1^{\circ} \mathrm{S}$. There is an occultation of $v$ Pisc, reappearance taking place on Sept. 14d. 0Ih. $56 \cdot 2 \mathrm{~m}$. Mercury rises about an hour before the sun on Sept. 1 and can be seen in the eastern sky. The planet is in conjunction with the sun on Sept. 14 and is not favourably placed for observation during the greater portion of the month. Venus sets an hour after the sun on Sept. 1 and 45 minutes after the sun on Sept. 30, attaining its greatest eastern elongation on Sept. 8. During the month the stellar magnitude of Venus varies from -3.9 to $-4 \cdot 2$. Mars and Jupiter are unfavourably placed for observation. Saturn rises at $2 \mathrm{~h}$. on Sept. 1 and at 0h. $19 \mathrm{~m}$. on Sept. 30 and can be sen in the constellation of Cancer in the morning hours. Its stellar magnitude is 0.5 during the month. Autumn equinox occurs on Sept. 23d. 16h.

\section{Announcements}

UNDER the auspices of the Central University, Quito, Ecuador, a general scientific review covering pharmacy, chemistry, physics and biology has been publisk 6 d under the title Revista de la Asociacion Esczela de Quimica y Farmacia. The Director (University, Quito, Apartado No. 166) is anxious to keep in touch with scientific developments everywhere and requests exchanges with similar reviews in America and the Old World.

The Royal Society of New Zealand invites applications for the T. K. Sidey Summer Time Award of a bronze medal and a prize of $£ 100$. The award is mado for scientific research on any kind of electromagnetic radiation (visible or invisible), including its relation to human welfare. Further information may be obtained from the Secretary, Royal Society of New Zealand, Victoria University College, Wellington, New Zealand.

THE report of proceedings of the twentieth conference of the Association of Special Libraries and Informglion Bureaux includes the papers presented at the Conference last September (see Nature, 156 605. 1945) together with notes on the discussions and reports on the work of the ASLIB Microfilm Sorvice and on the British Union Catalogue of Periodicals, and notes on the National Central Library and the Inter-Allied Book Centre. There is also a brief summary of a paper by Mr. E. Reid on the reform of the system of scientific publication by basing it on the individual paper as the unit. Charts displayed at the Conference showing the growth and distribution of the membership of the Association have been reproduced. Additions to the list of desk reference books given by Miss M. Bateman in her paper and suggested by members during the discussion are collected in a useful appendix to that paper. 